\title{
About the Geometry of Transition Pieces Relative to the Flat-Oval Tubing
}

Assoc. Professo

Technical University of Cluj Napoca

Romania

Georgiana Corsiuc

Lecturer

Technical University of Cluj Napoca

Faculty of Building Services

Romania

Ana-Maria Graur

Assistant Professor Technical University of Cluj Napoca Faculty of Architecture and Urbanism Romania
Air quality - a fundamental component of well-being - is assured through ventilation and/or air conditioning installations. The air transport is made by relatively large ducts equipped with auxiliary pieces to ensure the distribution of air in the rooms and the suction of contaminated air respectively. The less generalized tubing type with a flat-oval section cumulates the benefits of both circular and rectangular ducts. In this paper, the authors present the geometry of the reducing and enlarging pieces of the flat-oval ducts section, and of the transition pieces between the flat-oval sections and circular or rectangular sections, respectively. Using the descriptive geometry methods, one obtains the patterns required to construct these pieces.

Keywords: ventilation, flat-oval tubes, transition piece, development of surfaces, patterns.

\section{INTRODUCTION}

Economic and social developments have led people to become more and more sensitive to environmental conditions, and to the comfort they require in the areas in which they carry out most of their activities. Obviously, microclimate varies according to the purpose of the rooms, the type of activity, the geographical area and a series of subjective factors such as race, sex, age, metabolism, etc. Recently a new complex concept called "well-being" has been defined. It reflects people's fundamental physiological, psychological and social needs in relation to the environment [1]. Defining well-being is difficult because the senses and expectations of individuals vary from one to another or even to the same subject if the conditions change. But no matter what, one thing is certain: facilities that offer comfort have developed tremendously to meet the requirements imposed and finally standardized in each country.

An essential component in achieving a pleasant environment is the air quality, which is accomplished through ventilation and air conditioning installations. They provide a specific chemical composition and physical state of the indoor air.

The problems raised by these installations are caused by the large space the piping occupies, so in principle one of the following methods is used [2]:

- hiding pipes in false ceilings, providing rooms or special constructions; this solution has disadvantages related to the inefficient exploitation of usable space and entails additional costs for the building's construction;

- apparent installation of the tubing, which means integrating them in harmony with the volumes (spaces) designed and developed by architects and civil

Received: June 2018, Accepted: November 2018.

Correspondence to: Carmen Mârza, Technical

University of Cluj Napoca, Faculty of Building

Services, Cluj Napoca, Romania

E-mail: Carmen.Marza@insta.utcluj.ro

doi:10.5937/fmet1902337M

(C) Faculty of Mechanical Engineering, Belgrade. All rights reserved engineers; In this case, the installations must be conceived in such a way to perform both the technical function, for which they are designed, and the aesthetic function, so that to ensure visual comfort.

The last method is in agreement with the minimalist architecture style developed in the second part of the 20th century and which is still accepted by the modern and efficient men being in a continuous dynamic lifestyle.

Most of the ventilation and air conditioning installations were made with circular or rectangular/square sections tubes (Figure $1 \mathrm{a}$ and $\mathrm{b}$ ), each of them having advantages and disadvantages. In the last two decades the idea of using flat-oval ducts arose (Figure 1c) and represents a combination of the previously mentioned ones and cumulates their advantages [3].

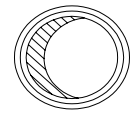

a.

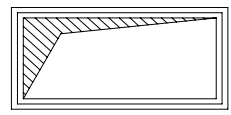

b.
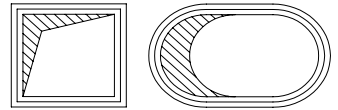

C.
Figure 1 Types of ducts [2], [4]

Among the advantages of flat-oval sections, we highlight [5]:

- for the same section, thus implicitly the same air flow rate, it requires significantly reduced installation heights compared to the circular section tube, which leads to more efficient use of the space - see Figure 2b;

- pressure losses are lower than in the case of rectangular sections, ensuring laminar flow of the fluid and significantly eliminating turbulences;

- low air flow resistance;

- reduces the propagation of sound waves and vibrations that are reflected by the surface of the tubing;

- aesthetic exterior appearance, which also recommends them for apparent installation in open spaces; 
- low cost for installation, maintenance and operation.

Until now, these have not been generally available on the market due to the conservatism of pipelines' producers and their retention that it would require additional investment, as well as beneficiaries not being sufficiently informed about the benefits of the flat-oval tubes.

The shape and dimensions of the cross-section of the flat-oval tubing are presented in Figure 2, where $b$ usually varies between $\mathrm{h}-2 \mathrm{~h}$. In exceptional circumstances, these values can be exceeded [6].

In order to highlight the advantages that the flat-oval pipeline has in terms of occupying usable space, elementary calculations were made.

Knowing that:

- the circular section area is:

$$
A_{1}=\pi R^{2}
$$

- the flat-oval section area is calculated:

$$
A_{2}=\pi\left(\frac{h}{2}\right)^{2}+b \times h
$$

where, one uses the following notations - Figure 2:

- $\mathrm{R}$ - the radius of the circular cross-section;

- $\mathrm{D}$ - diameter of the circular cross-section;

- $\quad b-$ the width of the linear portion of the flatoval cross-section;

- $\mathrm{h}$ - the height of the flat-oval duct;

- $\mathrm{d}$-diameter of the flat-oval cross-section.

By equalizing the two areas, in order to determine the relationship between the circular section diameter and the height of the flat-oval duct, the lower and upper usual boundaries were considered:

- for $b=h$ it results: $D=2 R=1.5 h$;

- for $b=2 h$ it results: $D=2 R=1.88 h$.

Consequently, for the same useful cross-section results a decrease in the height of the tubing, inclusively of the technical space, is between 50 and $88 \%$ - see Figure 2.

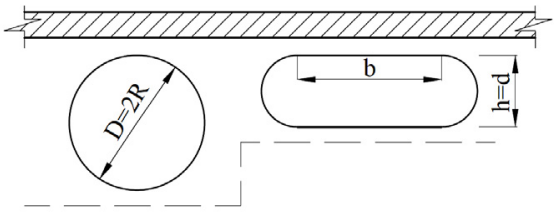

Figure 2. Comparative installation height for circular and flat-oval ducts

Regarding the linear load losses through the tubing, these are determined by applying Darcy's relationship [6]:

$$
\Delta p_{i}=\delta \cdot \frac{U}{A} \cdot \frac{\rho \cdot v^{2}}{2} \cdot I\left[N / m^{2}\right]
$$

where,

$\delta$ - non-dimensional friction coefficient;

$\mathrm{U}-$ section perimeter $[\mathrm{m}]$;

A - tubing section $\left[\mathrm{m}^{2}\right]$;

$\rho-$ the density of the air in the duct $\left[\mathrm{kg} / \mathrm{m}^{3}\right]$;

$\mathrm{v}$ - fluid velocity in duct $[\mathrm{m} / \mathrm{s}]$;

1 - the length of the tubing [m].
For flat-oval ducts, by replacing the perimeter and the section with the geometric formulas, the U / A ratio is obtained according to the diameter (d) and the height of the duct (h), for the two usual limit situations, as follows:

$$
\begin{aligned}
& \text { for } \mathrm{b}=\mathrm{h}=\mathrm{d} \frac{U}{A}=\frac{\pi+2}{d\left(\frac{\pi}{4}+1\right)}=\frac{2.88}{d} \\
& \text { for } \mathrm{b}=2 \mathrm{~h}=2 \mathrm{~d}: \quad \frac{U}{A}=\frac{\pi+2}{d\left(\frac{\pi}{4}+2\right)}=\frac{2.56}{d}
\end{aligned}
$$

For actual situations encountered in practice, for the same section of the pipe lower load losses result than in the case of pipes with a rectangular section, but higher than in the case of circular ones [6].

Applying (4) and (5) in the case of flat-oval ducts, it results a $12 \%$ decrease in pressure loss in the case of $b=$ $2 \mathrm{~h}$ compared to the $\mathrm{b}=\mathrm{h}$ version, in similar conditions, both in terms of fluid flow as well as the material from which the pipe is made.

In this paper the authors present some of the component pieces necessary for flat-oval tubing and implicit aspects related to their geometry.

\section{TRANSITION PIECES RELATIVE TO THE FLAT- OVAL TUBING}

Because the air treatment and transport devices have rectangular or circular sleeves, connecting pieces that make the transition between rectangular and flat-oval, respectively circular and flat-oval, are required. Also, reducer pieces are required to make the transition between the same section type (i.e. flat-oval) but of different sizes [7].

Likewise, to achieve the fluid transport and to follow the imposed route for the air distribution to the rooms or the suction of the polluted air from the rooms, more pieces such as elbows, most frequently to $90^{\circ}$, branches or bifurcations are required. These can be made on the circular or rectangular surface.

To reduce or increase the flat-oval section, the piece represented in Figure 3 is used. For this type of transition, if the piece is centric, the lateral (side) surface is composed of cone frustums and trapeziums which also break into elementary triangle forms [5]. To obtain the true size of the generatrices, the vertex of the cone from which the frustum was obtained must be determined. By using the method of the revolution about the vertical axis drawn through the vertex of the cone, the true length of the cone generatrices are determined, from which the length of the frustum generatrices are kept. By means of the real lengths thus obtained, the development of the piece was built. For the clarity of the perception the piece was represented in isometric orthogonal axonometry.

In Figure 4 a piece that makes the transition between a rectangular section and a flat-oval section is represented [4], at which the height of the flat-oval duct is equal to the small side of the rectangular section. The development of the piece is composed of conic nappes, triangles and trapeziums. To determine the true size of 
the geometric elements, a rotation around the vertical axis is made in order to transform the oblique generatrices in frontal lines. Thus, in the rotated vertical projection their real length results. In this way are obtained the sides of the triangle, which are identical with the vertical apparent contour generatrices

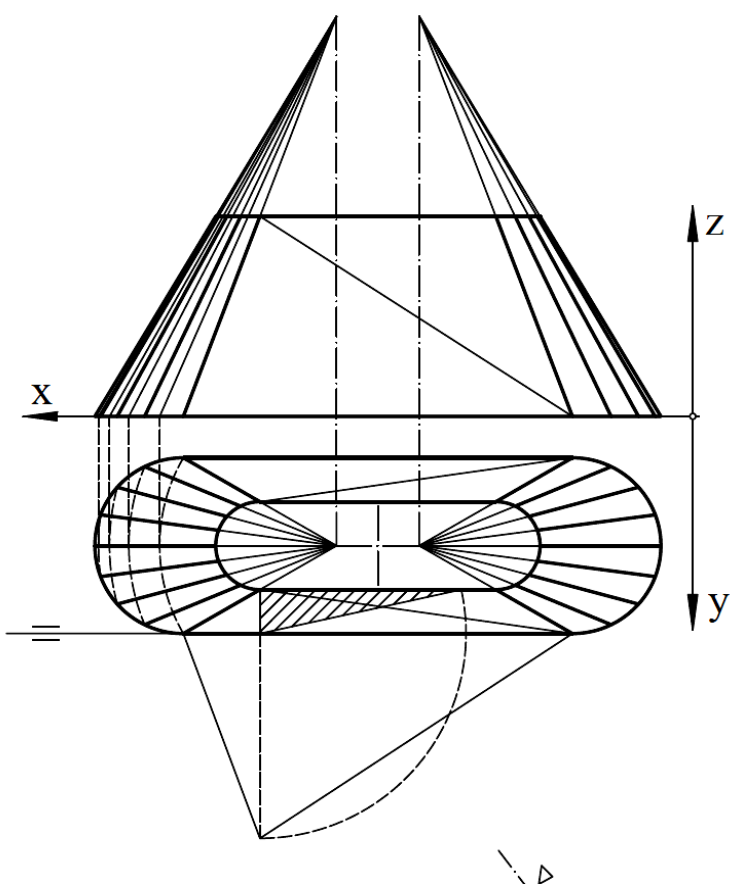

a. orthographic projections

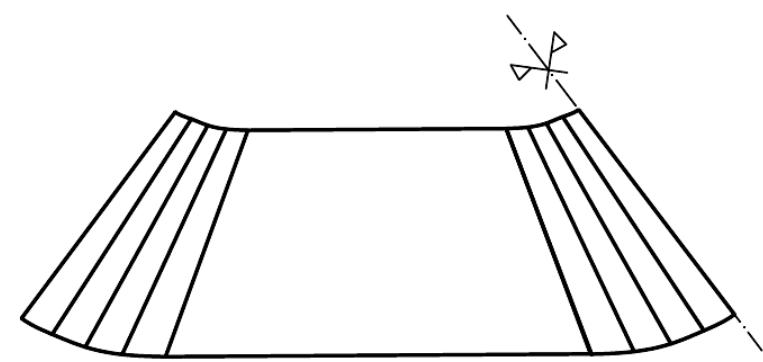

b. real size of the surface

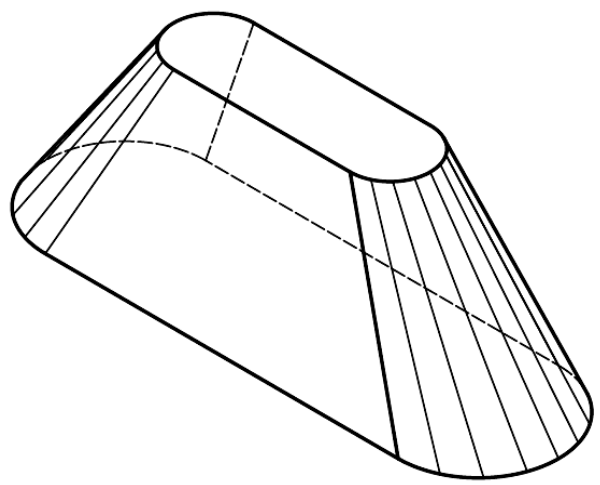

\section{c. axonometric view}

Figure 3. Reduction piece between the two flat-oval crosssections

A particular case of this piece is when the $(b+2 r)$ dimension of the flat oval duct is equal to the large side of the rectangular section. The solution is similar, with the specification that in this case the two triangles are in profile planes so that we have them in real size in the lateral projection.

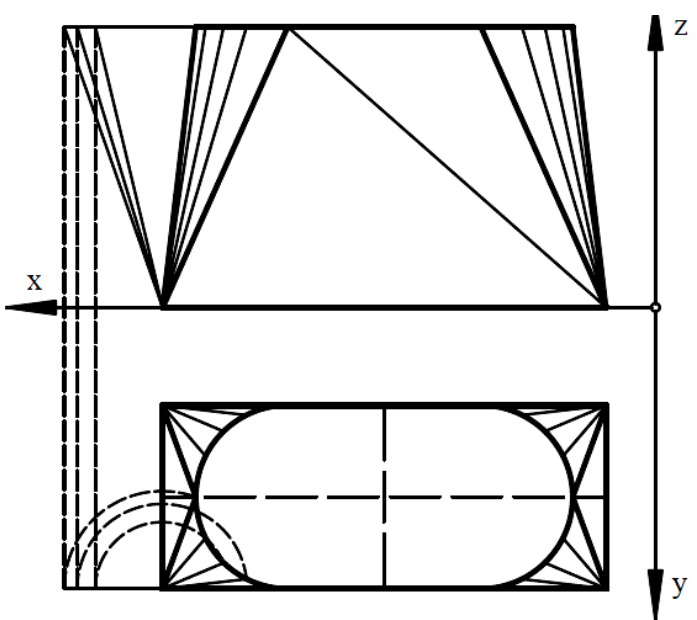

a. orthographic projections

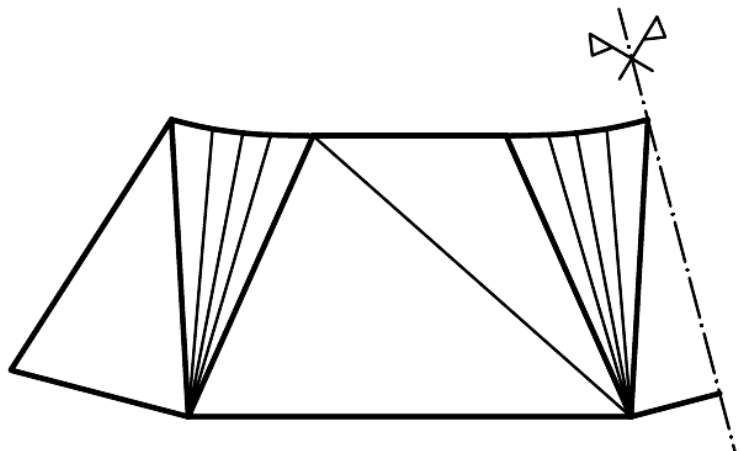

b. real size of the surface

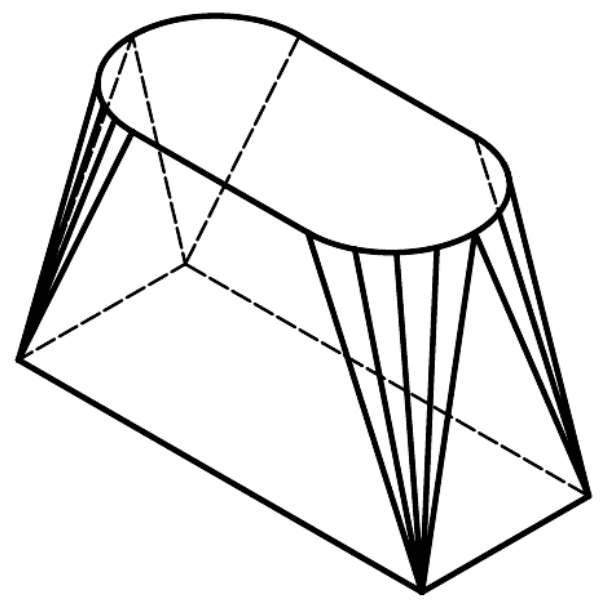

c. axonometric view

Figure 4 The transition piece between the rectangular and the flat-oval cross-sections

Figure 5 represents the transition piece between the flat-oval section and the circular one, where the diameter of the circular section is equal to the h-side of the flat-oval duct, respectively with the diameter of the circular area of the flat-oval duct. In this case, the development is composed from a succession of oblique cylinder nappes and triangles. In fact, one can notice that the cylinder is in the particular position of a frontal cylinder, which implies that one has the true length of the generatrices in the front view. In order to achieve the development surface, the section with a normal plane on the cylindrical nappes generatrices was used, obtaining in this way the stretch-out line. 


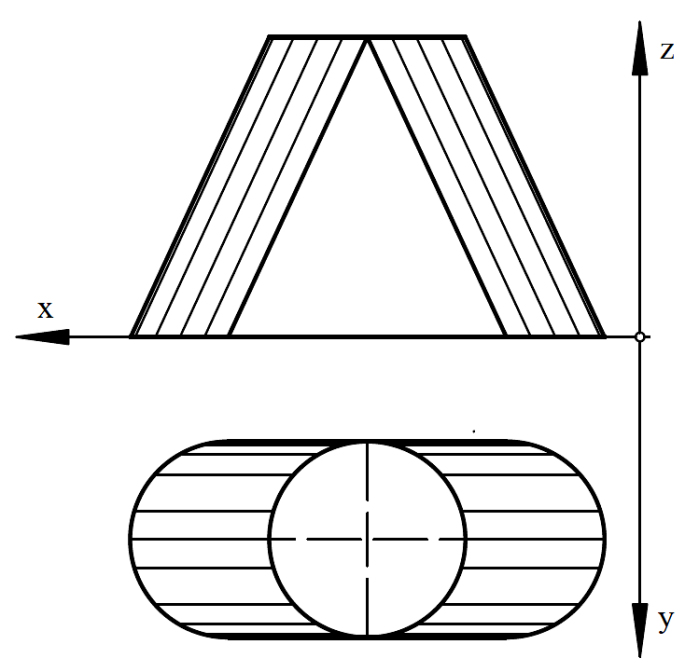

a. orthographic projections

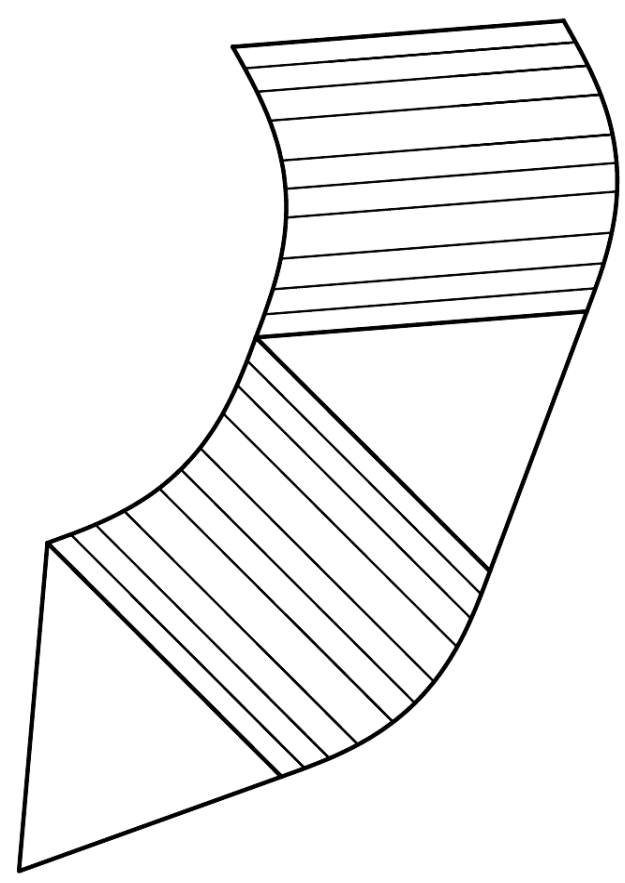

b. real size of the surface

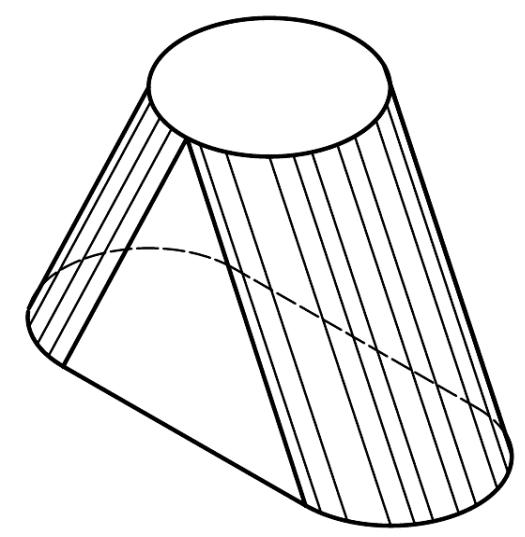

c. axonometric view

Figure 5. The transition piece between the circular section and the flat-oval section $(D=h)$

In Figures 6 and 7 are represented transition pieces between circular and flat-oval section in orthogonal and in axonometric projections. The authors propose two solutions for solving the requirement.

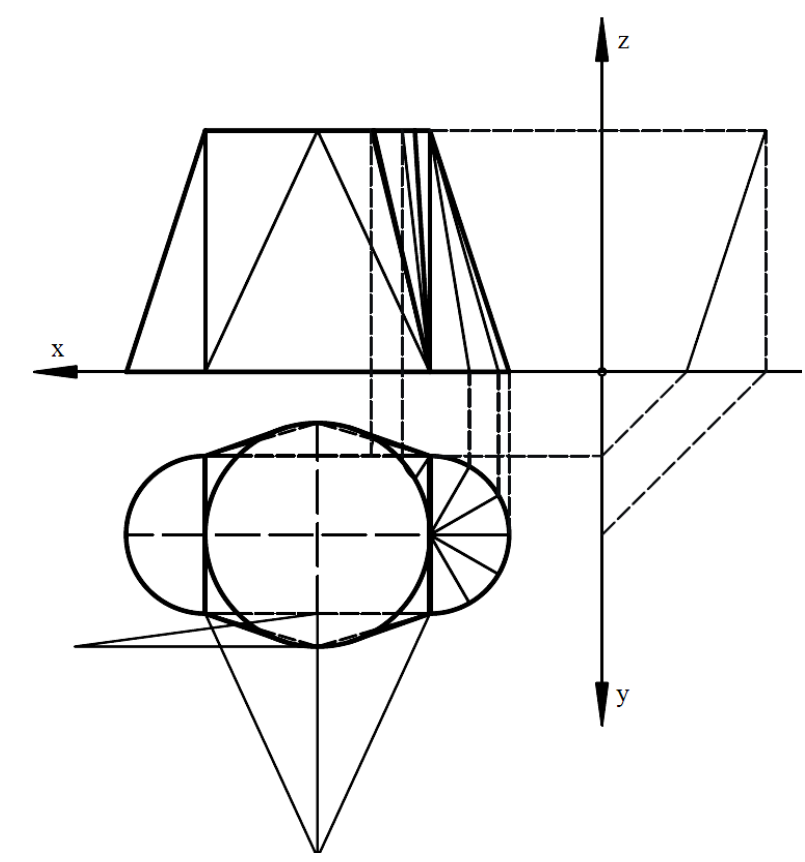

a. orthographic projections

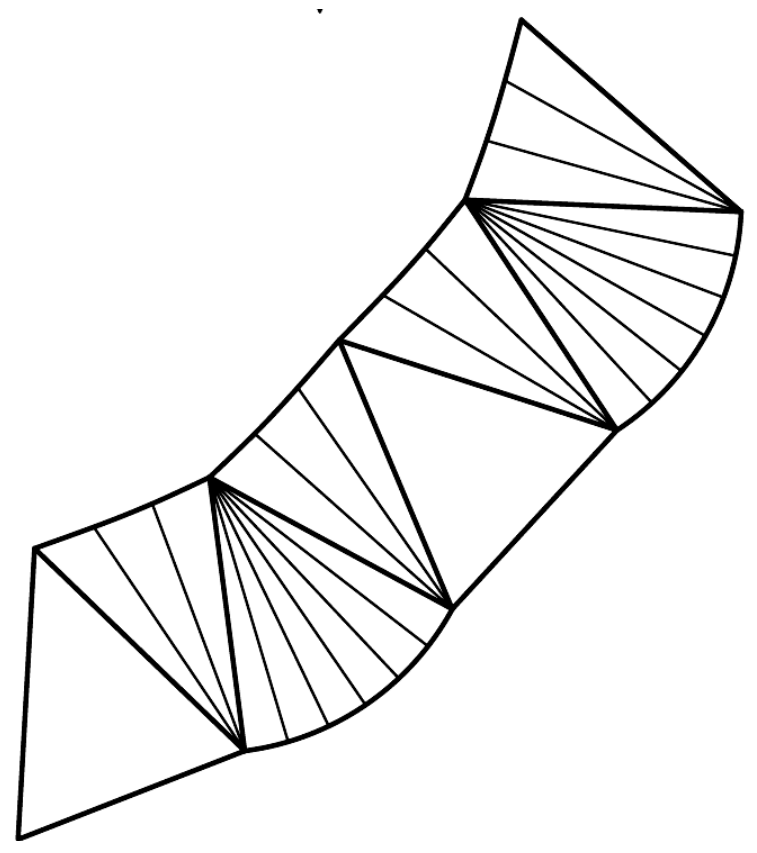

b. real size of the surface

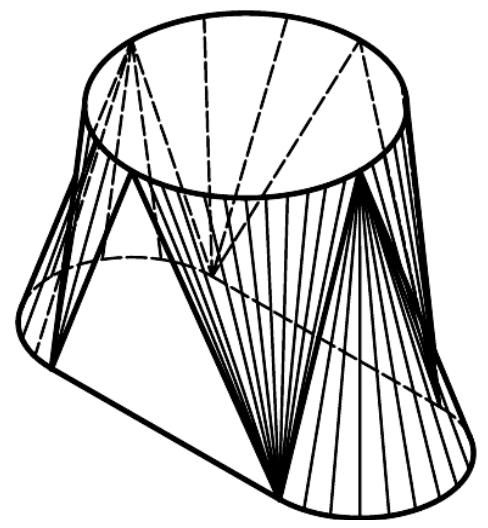

c. axonometric view

Figure 6. Transition piece between the circular section and the flat-oval section $(D>h)$ - First solution 


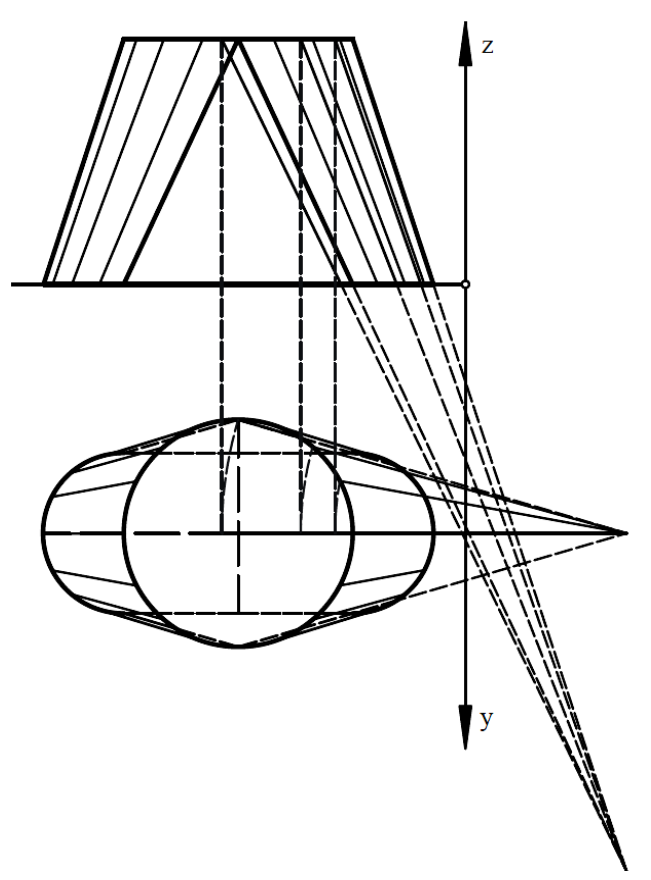

a. orthographic projections

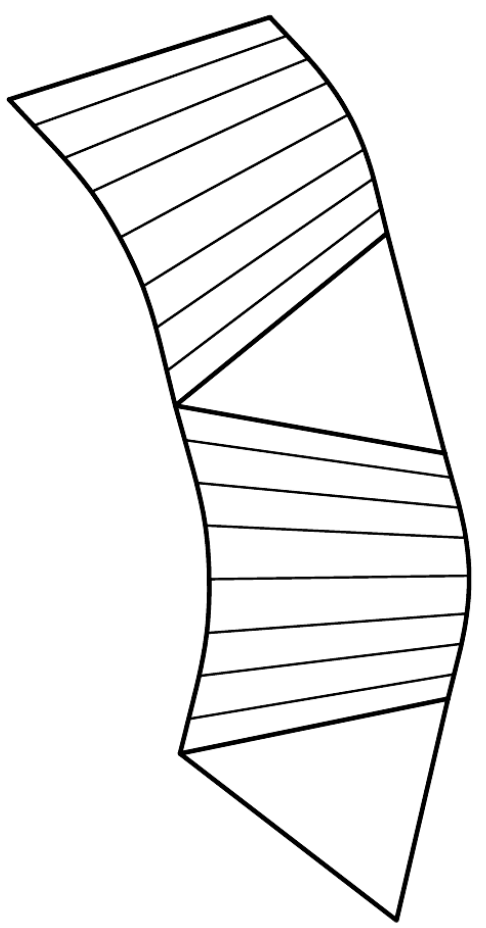

b. real size of the surface

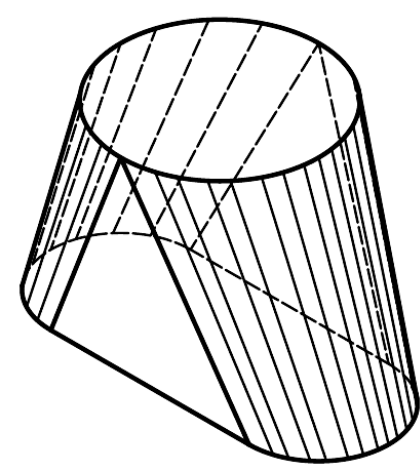

Figure 7. Transition piece between the circular section and the flat-oval section $(D>h)$ - Second solution
The first solution (Figure 6) gives the development of the transition piece being composed by triangles and nappes of cone having the vertices alternating on the two bases [7]. The true length of the generatrices was obtained by two rotations around the vertical axes taken through the vertices of both cones. For the accuracy of the drawing, the true size of the triangle was obtained by coincidence with horizontal plane of projection.

The second solution (Figure 7) proposes the development consisting of triangles and truncated cone (frustum of the cone) [8]. To solve it, is necessary to determine the vertex of the cone from which the frustum was obtained. For the true length of the generatrices, a rotation was made around the vertical axis through the cone vertex, from which the length of the generatrices of the frustum was taken.

The last one assures a continuous surface and for this reason is more preferred.

Due to their advantages, as presented in the first part of the paper, the flat-oval ducts are used in some applications. In Figure 8 is represented the solution proposed by the authors in the CADVENT program, presented at a specialized conference for a ventilation installation with the transition from rectangular section tubing to flat-oval, imposed by the technical space available, and in Figure 9 shows a portion of the air conditioning plant at a Turkish seaside pool.

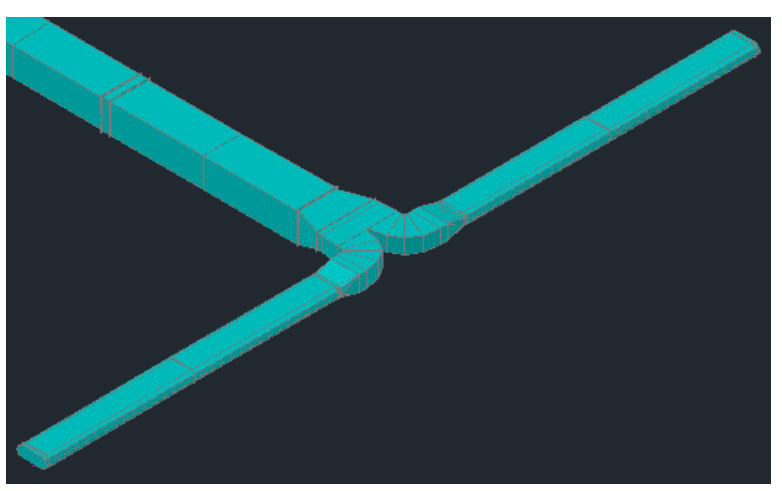

Figure 8. 3D representation in CADVENT [4]

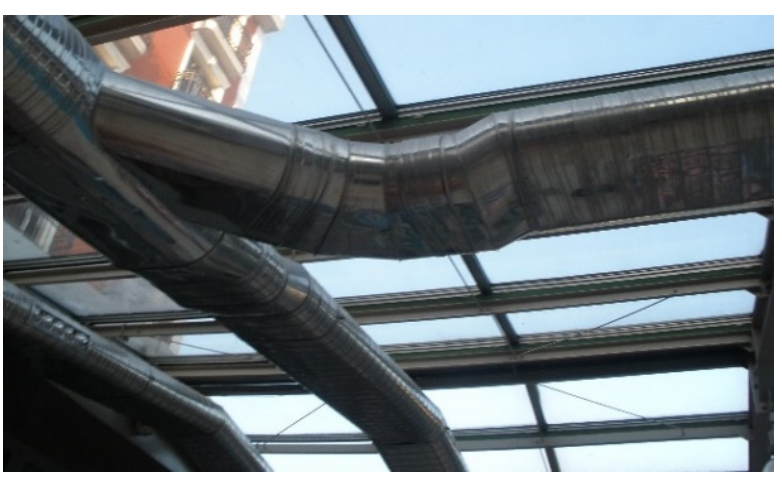

Figure 9. Flat-oval ventilation tubing [4]

\section{CONCLUSION}

The incidence of repeatability in the field of ventilation /air-conditioning installations is low, most of the solutions being unique due to the geometric shapes, the purpose and the occupancy degree of the buildings, the technical spaces available, the air flow transported as well as the aesthetic and functional requirements 
requested by the beneficiaries. Considering the large dimensions of the pipe section, the construction of the piping and especially of the transition pieces needed to ensure the route of the pipes, knowledge of descriptive geometry is required. In this way one obtains more accurate developments and pieces ensuring tight joints and a laminar flow of the agent, thus, another benefit of these types of installations is provided, namely a lower acoustic impact.

For obtaining high precision patterns of the auxiliary pieces used on the ventilation/air conditioning tubing, calculus algorithm can be implemented in computer numerical control (CNC) machines.

Because these devices involve high costs, there is the possibility of implementing platforms to reuse some obsolete $3 \mathrm{D}$ printers for performing simple manufacturing operations using low cost hardware components and open source software [9].

\section{REFERENCES}

[1] Boon, L. O.: Beyond environmental comfort, Routledge Taylor and Francis Group, London and New York, 2013.

[2] Mârza, C., Corsiuc, G.: Study regarding the geometry of some connecting pieces for circular ducts, in: Proceedings of the 5th International Scientific Conference on Geometry and Graphics moNGeometrija, 23-26.06.2016, Belgrade, Serbia, pp. 403-409.

[3] *** RO Standard 185-89: Fittings and auxiliary pieces for pipes (in Romanian).

[4] Mârza, C., Deac, A. and Corsiuc, G: Methods for representing the tubing of ventilation/airconditioning plants, Journal of Industrial Design and Engineering Graphics, Vol. 10, Special issue ICEGD, fascicle 2, pp. 31-36, 2015.
[5] https://www.ditrade.md/product/tubulatura-platovala-dt-tpo?cat_id, Accessed in 27.11.2017.

[6] ***Handbook of Ventilation and Air Conditioning Installations (in Romanian), ARTECNO, Bucharest, 2010.

[7] Mârza, C., Corsiuc, G. and Drăgan, D.: Descriptive Geometry- theory and applications (in Romanian), UT Press, Cluj Napoca, 2016.

[8] Moncea, J.: Descriptive Geometry (in Romanian), Bucharest, 1982.

[9] Quatrano, A., De Simone, M. C., Rivera, Z. B. and Guida D., Development and Implementation of a Control System for a Retrofitted CNC Machine by Using Arduino, Journal FME Transactions, Vol. 45, No.4, pp. 565-571, 2017.

\section{О ГЕОМЕТРИЈИ ПРЕЛАЗНИХ КОМАДА У ОДНОСУ НА ПЛОСНАТО-ОВАЛНЕ ЦЕВИ}

\section{К. Марза, Г. Корсиук, А-М. Граур}

Квалитет ваздуха - основна компонента благостања обезбеђује се кроз инсталације за вентилацију и/или климатизацију. Транспорт ваздуха врши се релативно великим цевима који су опремљеним помоћним деловима како би се обезбедила дистри-буција ваздуха у просторијама, као и усисавање контаминираног ваздуха. Мање генерализовани тип цеви са равним овалним деловима обједињује предности и кружних и правоугаоних цеви. У овом раду аутори приказују геометрију смањивања и увећавања попречних пресека пљоснато-овалних цеви, као и прелазних делова између пљоснато-овалних пресека и кружних или правоугаоних профила. Користећи методе дескриптивне геомет-рије, добијамо обрасце потребне за конструисање ових делова. 